\title{
Toxic elements in the groundwater of Budapest, Hungary
}

\author{
István Zsámbok ${ }^{1}$, Anita Andó ${ }^{1}$, László Kuti ${ }^{1}$, András Sebők ${ }^{2}$ \\ ${ }^{I}$ Department of Environmental Geology, Geological and Geophysical Institute of Hungary, Budapest, \\ Hungary \\ ${ }^{2}$ Faculty of Agricultural and Environmental Sciences, Szent István University, Gödöllö, Hungary
}

\begin{abstract}
The birth of urban geologic maps (which are considered environmental-geologic themed maps) and the progress in development of their content and design were driven by the growing importance of addressing environmental problems, and the increasing complex utilization of urban areas. Therefore, MÁFI and, since 2012, the MFGI Department of Environmental Geology, have prepared a series of maps for the local authorities of Budapest. These maps usually focus on the problems of urban planning from the viewpoint of geology, hydrogeology, and water chemistry, and as experience shows, they prove to be excellent tools in decision-making processes. This paper examines the chemical content of groundwater, which is one of the main indicators of the state of the environment. According to the everyday experience of the authors it is very useful to understand the state of both quality and quantity of subsurface and surface water. In a recent series of research work we measured the zinc, copper, boron and arsenic level of the groundwater in 10 districts of Budapest.
\end{abstract}

Keywords: urban geology, groundwater chemistry, toxic elements

\section{Introduction}

In their urban geologic programs the Geological Institute of Hungary (MÁFI) and its successor the Geological and Geophysical Institute of Hungary (MFGI) have been preparing urban geology maps of the Budapest districts since 2001 (MFGI-MÁFI 2001-2013). A profound knowledge of the chemical content of groundwater is important for the estimation of the urban geologic state of the areas.

Pollutants - although in an attenuated form - are able to spread over a long distance from the background areas of the flows. Therefore, the data obtained from the

* Corresponding author; Stefánia u. 14, H-1143 Budapest, Hungary; E-mail: zsambok.istvan@mfgi.hu Received: October 28, 2014; accepted: October 28, 2014 
subsurface patterns, taken from a pre-established network of test points, are very useful in characterizing the environmental geologic state of a relatively large area. Even the smallest amount of an element can be a very important indicator, as it might be a signal of an as-yet unknown source of pollution.

Apart from the physical and chemical characteristics of the material, the geologic set-up and hydrogeologic properties (e.g. the content of the aquitard/aquifer layers, the velocities and directions of the flow, and the groundwater depth) are also very important factors in examining the spreading of materials in the water.

Based on the factors mentioned above, we examined the chemical content of urban groundwater and qualified the environmental (pollution) state of the areas. Most of the samples were usually from already existing wells: these are from the old monitoring network of MÁFI and FÖMTERV, or dug wells. With no other possibility available, test holes were drilled for sampling as well. The chemical analysis was carried out in the laboratories of the MFGI (formerly MÁFI).

At this time 372 analyses of hydro-chemical factors and toxic elements are available from 10 districts of Budapest. Among the total range of toxic elements observed, we focus only on copper, zinc, boron and arsenic concentration.

\section{Analytical methods}

Sampling was performed by the colleagues of the Institute between 2001 and 2013, in accordance with the standard on water sampling (MSZ 21464:1998). The samples were collected in plastic bottles prepared by the laboratory of the MFGI (MÁFI 5.8:2012 procedure of preparatory works). The temperature, $\mathrm{pH}$ and conductivity of the water samples were measured both in the field and in the laboratory, using a WTW Multiline $\mathrm{P} 4$ combined $\mathrm{pH}$ and specific conductivity measuring device. The Laboratory of the MFGI is currently accredited by the National Accreditation Body (No. of certification: NAT-1-1302/2012). Metal analysis was carried out using an ICP-AES Jobin Yvon ULTIMA 2C inductively coupled plasma atomic emission spectrometer (MSZ 1484-3:2006). The results were presented in lab reports; anions in $\mathrm{mg} / \mathrm{l}$, metals in $\mu \mathrm{g} / \mathrm{l}$. Data obtained from the lab reports were processed with the Surfer 8 software. The results were interpreted according to the legislation in force on the limit values of groundwater (joint decree 6/2009. (IV. 14.) KvVM-EüM-FVM)

\section{Results}

Zinc

Zinc is the most commonly identified element, since it was present in all of the examined samples. The threshold limit $(\mathrm{B}=200 \mu \mathrm{g} / \mathrm{l})$ was crossed in 53 samples $(14.5 \%)$. In two points it reached the $10-12,000 \mu \mathrm{g} /$ limit, and in one case the concentration was above $24,000 \mu \mathrm{g} / \mathrm{l}$. The concentration of zinc at a certain point is displayed on the map (Fig. 1) by the multiplier factor of the limitation (for example: $1 \times, 2 \times, 5 \times$, 
$10 \times, 25 \times, 50 \times, 100 \times, 125 \times)$. Higher values densely occur in District 7 . In other places higher values occur only occasionally and separately, relatively far away from each other.

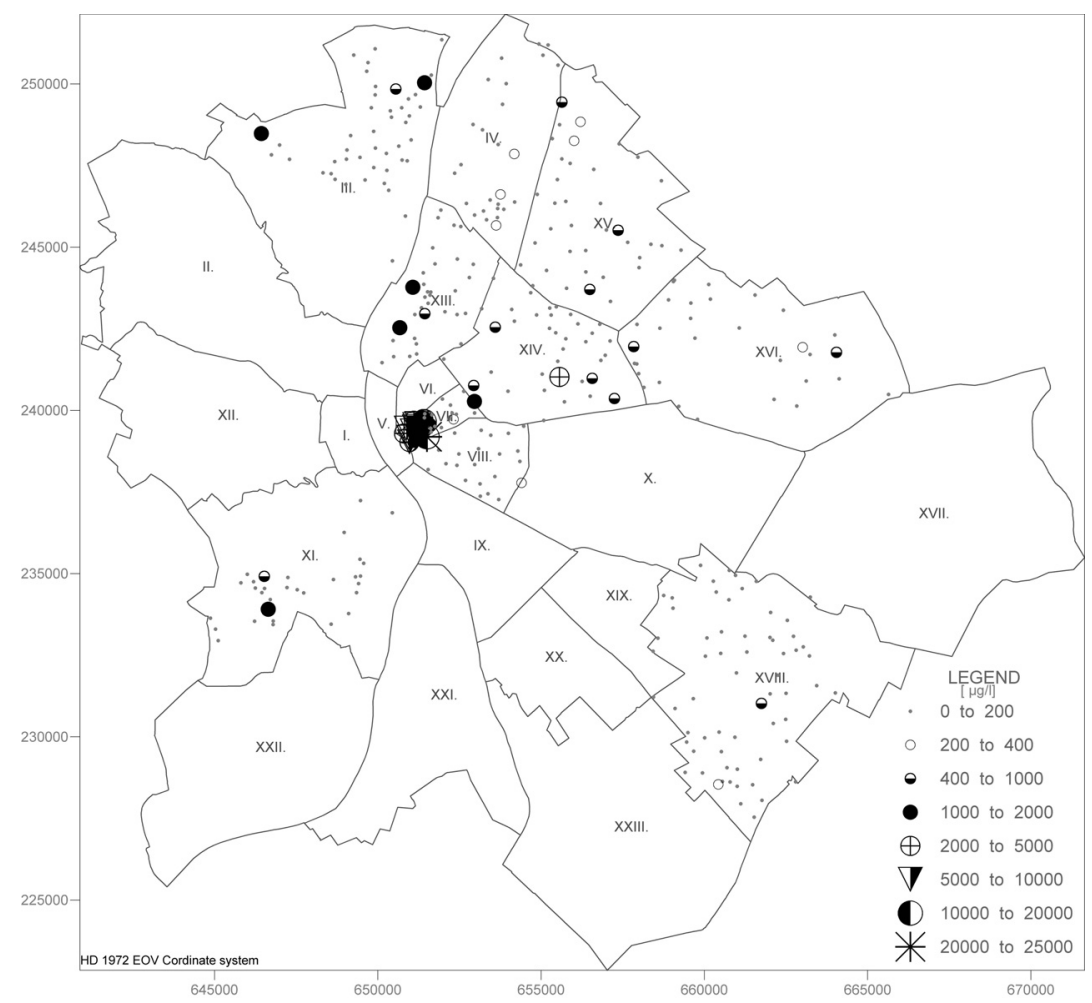

Fig. 1

Concentration of zinc in Budapest's groundwater

In accordance with 6/2009. (IV.14.) KvVm-EüM-FVM regulation (Hungary), the limit of contamination ("B") in groundwater, concerning zinc: $\mathrm{B}=200 \mu \mathrm{g} / \mathrm{l}$

There is at least one point in each district in which zinc oversteps the $\mathrm{B}=200 \mu \mathrm{g} / \mathrm{l}$ multiple times. Districts 4 and 18 are the least polluted by this element. The most polluted area is bordered by Rákóczi Street, Károly Ring Road, Király Street, and Erzsébet Ring Road. In this area zinc occurred in 20 out of 36 samples in a 3-50× higher concentration than the limitation. The most polluted point is Rákóczi Street 32, which officially belongs to District 8, but technically counts as part of this area.

Sampling in District 7 (Fig. 2) was carried out upon the request of the local authorities. The measurements were repeated in 2006. No significant changes were noted in the data, which means that either the source of the pollution is still present, or the groundwater is not cleaned up. 


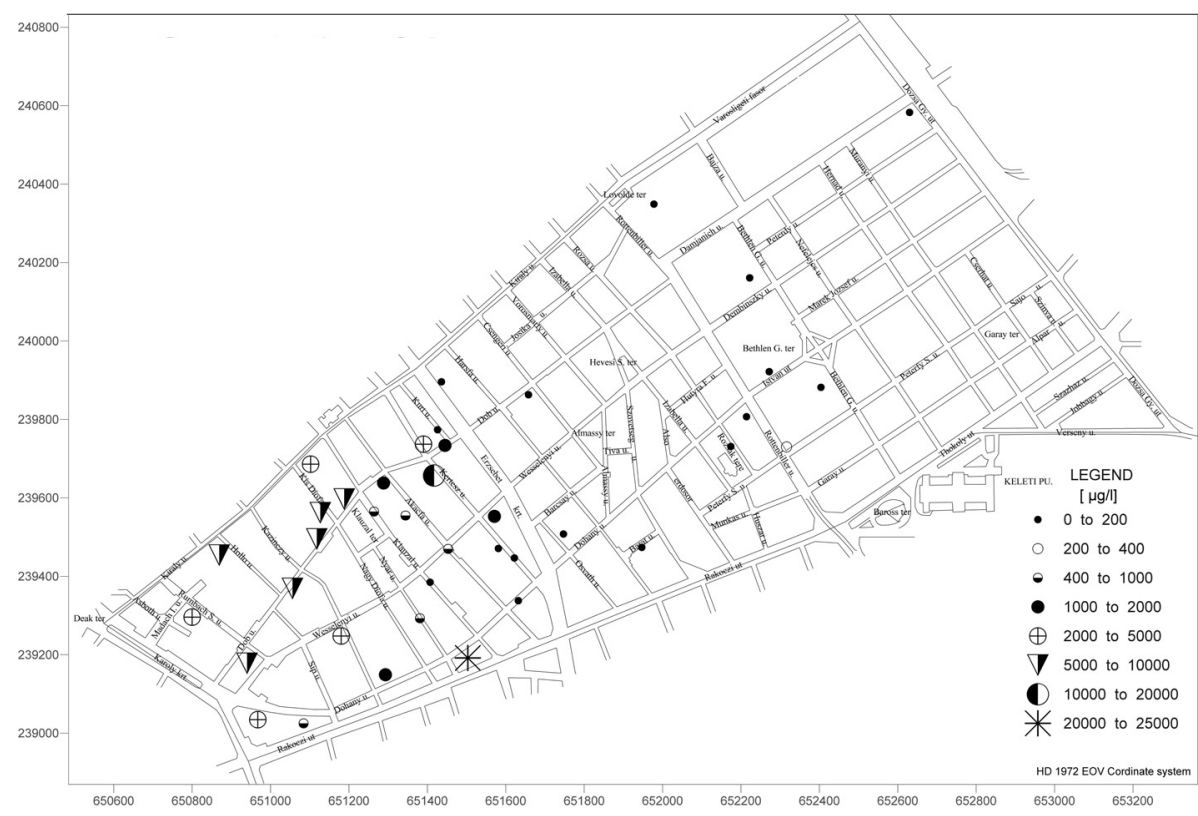

Fig. 2

Concentration of zinc in Budapest district No. VII

In accordance with 6/2009. (IV.14.) KvVm-EüM-FVM regulation (Hungary), the limit of contamination ("B") in groundwater, concerning zinc: $\mathrm{B}=200 \mu \mathrm{g} / 1$

When researching the possible reasons of extremely high zinc concentration, several factors shall be taken into consideration.

District 7, also known as Erzsébetváros, with its $2.1 \mathrm{~km}^{2}$ size, is the second smallest district of Budapest. Many of its houses are under national protection and they are often 100 years old or more. The houses are built densely, and it is featured as one of the most densely inhabited areas, not only of Budapest, but also of Europe. As opposed to this, the scale of green areas is the smallest in comparison with the other district: it is only $0.3 \mathrm{~m}^{2} /$ capita. These areas and public parks are small and distinct; they cannot form a connected green network.

The first of the reasons for the extremely high concentration of zinc in the area is perhaps the corrosion of old water-pipe systems of the buildings, which require significant reconstruction. The second (and perhaps the principal) reason is that acid rains wash zinc into the soil (Förstner 1993).

The third reason could be that the sampling pipes (constructed in the 1950s) were made of 2" metal pipes. Although the samples were collected after careful pumping, the zinc, adsorbed in clay fractions, can sole back and pollute the groundwater. With the construction of new holes and the usage of PVC pipes, this problem can be con- 
trolled; a further urban geologic mapping of the district might provide an occasion for this.

In other districts, pollution occurs only in isolated points and no further study was made of its environmental impacts. The origin of zinc content in the soils is explained by several reasons in the literature. Zinc can be injected into the soil as a result of industrial processes (Förstner 1993). High concentration can occur in the neighborhood of metal construction, pesticide-making, cleaning works, paint, plastic and tire manufacturers, and growing zinc pollution is caused by a growing amount of solution from household waste. Rainwater also washes a considerable amount of zinc into the soil from metal roofs and immediately into the water.

Purifying zinc from groundwater is practically impossible. After terminating the source of pollution, with the knowledge of geologic and hydrogeologic correlations, the future of the zinc content is predictable. A large water transport (inflow/outflow) can decrease the zinc concentration below the limit. If only short water transportation occurs, only the adsorption of clay minerals can decrease the concentration - which is a very slow process (Földváriné Vogl 1975).

\section{Copper}

Copper pollution is significantly lower than that of zinc (Fig. 3). From the 372 sampling points, copper oversteps the $\mathrm{B}=200 \mu \mathrm{g} / \mathrm{l}$ limitation in only seven cases.

In District 7, which has already stuck out with its high level of zinc pollution, four copper-polluted points occur. They come together with a high zinc concentration, and can therefore be counted as a complex pollution. In three cases there is only a slight overstep of the limits, and all of these come together with a high level of zinc. The most significant is the sample from Rákóczi Street 34, in which copper occurs with a 1,854 $\mu \mathrm{g} / \mathrm{l}$ concentration, and a zinc one of $24,453 \mu \mathrm{g} / \mathrm{l}$. The other 3 water samples are from separately situated points, but there is one complex $\mathrm{Zn}-\mathrm{Cu}$ point in District 13, Dagály Street 20.

According to the statistics, copper and zinc pollution is from industry and communal waste in a ratio of $50-50 \%$. The corrosion of water pipes causes a significant pollution of copper, and a somewhat smaller pollution of zinc (Förstner 1993).

Boron

Boron was also traceable in all samples. It stepped over the limitation ( $\mathrm{B}=500 \mu \mathrm{g} / \mathrm{l})$ in $25.2 \%$ of the total samples, in $18.3 \%$ it was twice as high, in 8.1 percent it was $2-5$ times as high.

Figure 4 displays the areal spread of the pollution. The periphery districts are usually cleaner, although Districts 9 and 18 shows the opposite. Here the element was measured in a 5-10 times higher concentration than the limit. In 18 districts industrial sources are not significant. In the suburbs the pollution is mainly from the leakage of household wastewater. A very high level of pollution $(17,770 \mu \mathrm{g} / \mathrm{l})$ was detected in District 4, in the well of Megyeri Street, which is possibly the result of a former acci- 


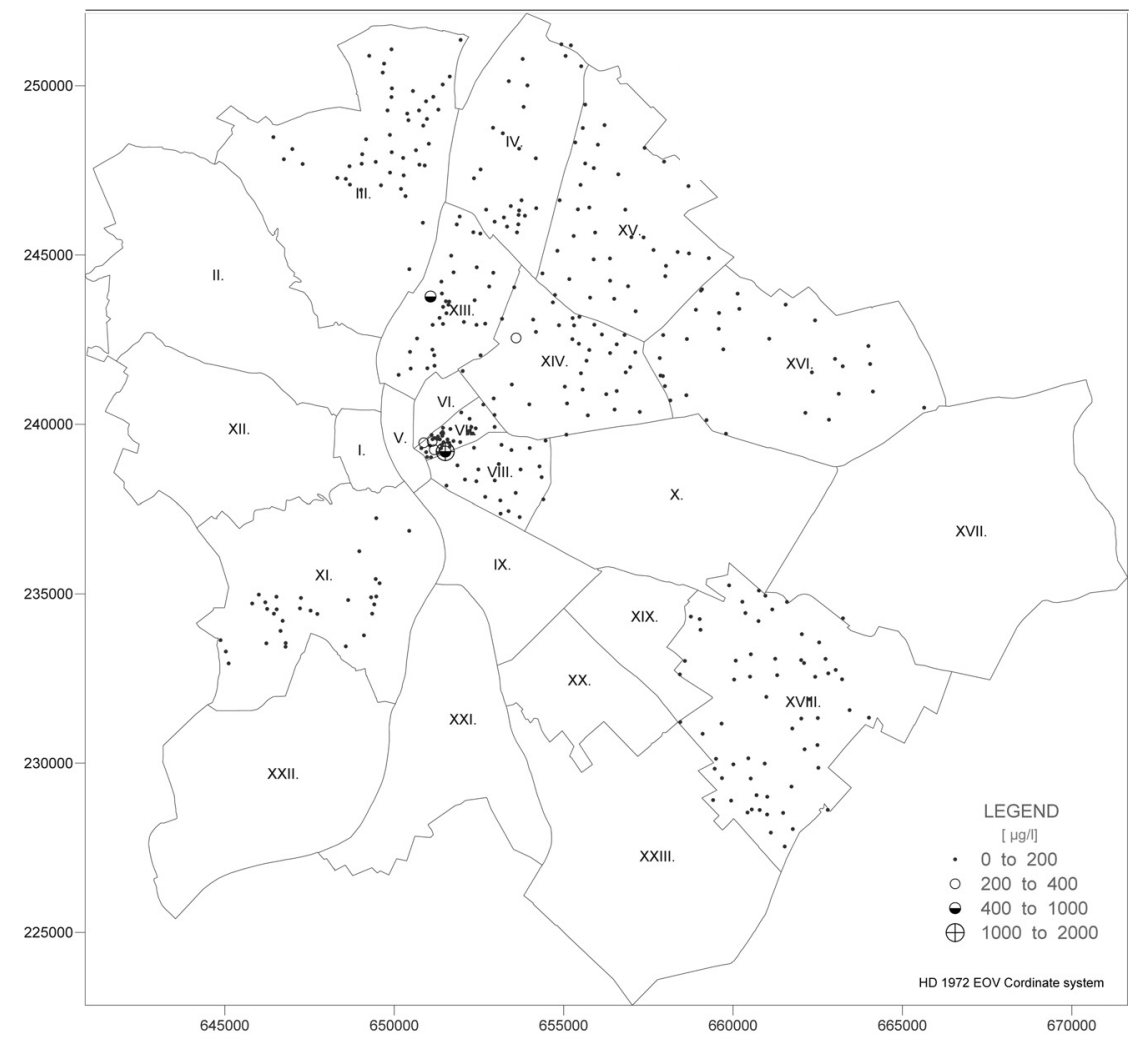

Fig. 3

Concentration of copper in Budapest's groundwater

In accordance with 6/2009. (IV.14.) KvVm-EüM-FVM regulation (Hungary), the limit of contamination ("B") in groundwater, concerning copper: $\mathrm{B}=200 \mu \mathrm{g} / 1$

dent (Guidelines for..., WHO Geneva). (There is a LIDL warehouse in the neighborhood.)

For a presently unknown reason arsenic concentration was not analyzed in Districts 8 and 18. In 129 cases out of 277 , arsenic concentration did not occur in a detectable amount, and in 124 cases it did not reach the limiting threshold $(B=10 \mu \mathrm{g} / \mathrm{l})$. The threshold was overstepped in the case of 17 samples and in 7 samples it was overstepped multiple times.

Arsenic

The highest arsenic pollution was detected in District 13 (Fig. 5). This quite large area is situated between Angyalföld, Fáy Street and Béke Square. The most polluted point provided sample 1328, as limitation-crossing ammonium, sulfate, nitrate, boron and arsenic contents $(87.5 \mu \mathrm{g} / \mathrm{l})$ come together with a high molybdenum $(32.9 \mu \mathrm{g} / \mathrm{l})$ 


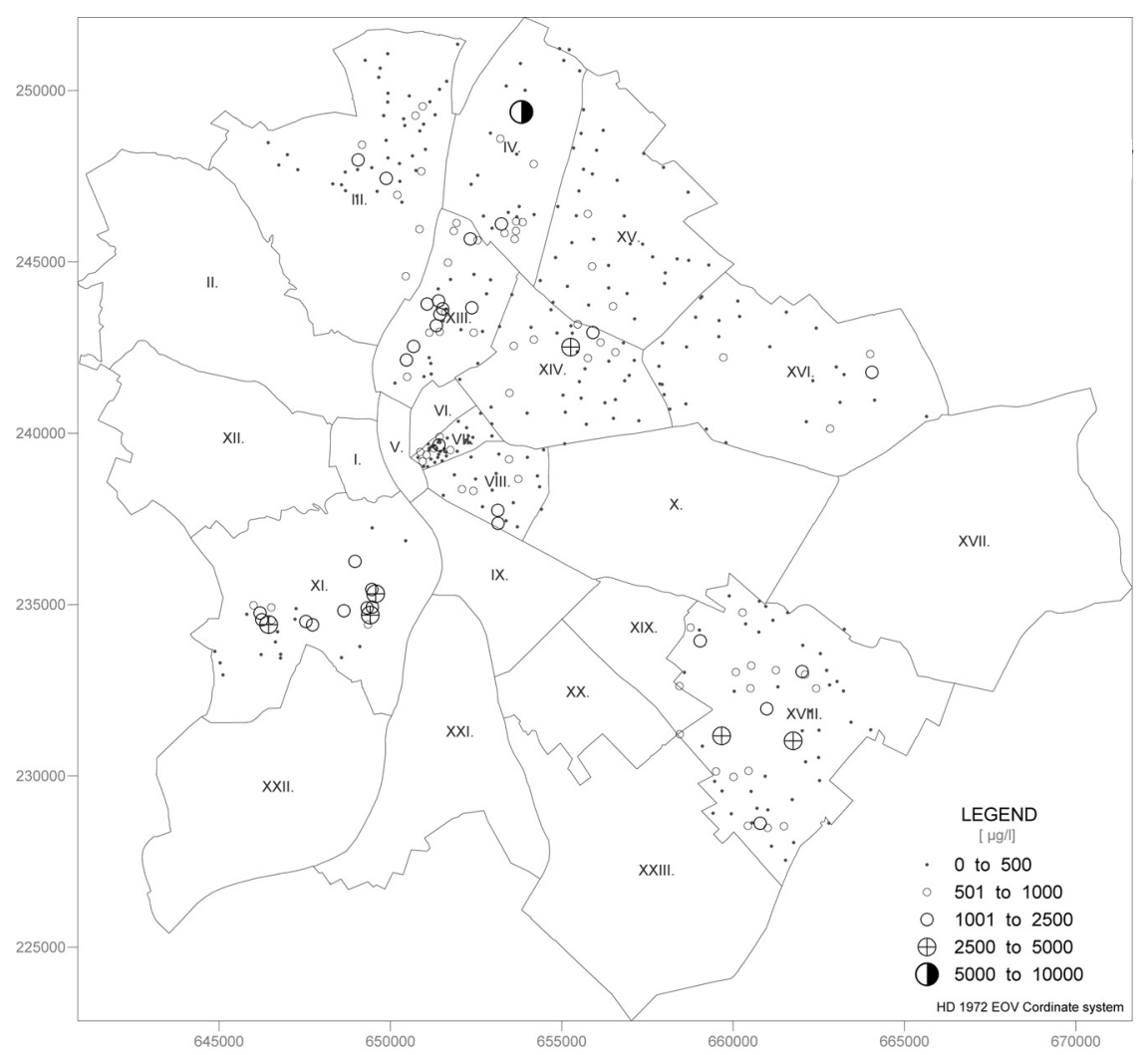

Fig. 4

Concentration of boron in Budapest's groundwater

In accordance with 6/2009. (IV.14.) KvVm-EüM-FVM regulation (Hungary), the limit of contamination ("B") in groundwater, concerning boron: $\mathrm{B}=500 \mu \mathrm{g} / 1$

concentration as well. To prove this, a further control point is needed from this area. This sample is based on the research well of the sports center of Fáy Street. The drill encountered a mixed clinker layer (to $3.1 \mathrm{~m}$ measured depth), a peat layer (to $3.6 \mathrm{~m}$ measured depth) and a silt layer, filled with plant remains. Arsenic pollution possibly comes from clinker and silt, but the occurrence of other polluting materials (such as nitrate, ammonium, and molybdenum) can indicate an artificial source. The district was home to a former bus station, storage buildings, and metal manufacturing works. In Béke Square the pollution is possibly caused by residuum, but it does not overstep the limitations more than two times (Földváriné Vogl 1975; Förstner 1993).

In District 15 a high $(64.6 \mu \mathrm{g} / \mathrm{l})$ concentration stands out, both for its strange location and its high concentration. The sample was taken closely to the Csömör streamlet, from a hole dug directly for sampling purposes. The arsenic concentration possibly co- 
mes from the organic layers of the streamlet. To prove this theory, a control well is needed from a point close to the original one.

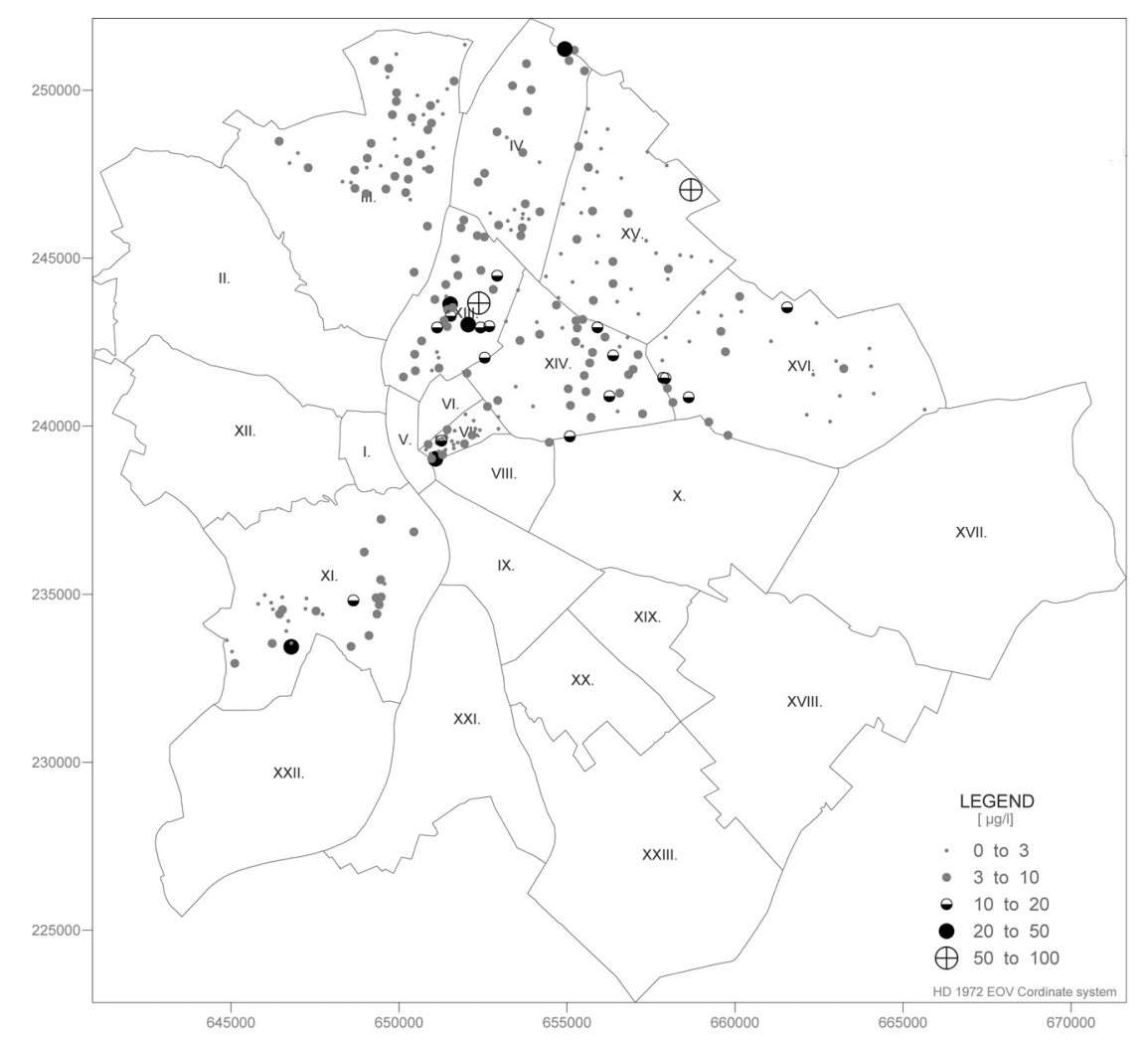

Fig. 5

Concentration of arsenic in Budapest's groundwater

In accordance with 6/2009. (IV.14.) KvVm-EüM-FVM regulation (Hungary), the limit of contamination ("B") in groundwater, concerning arsenic: $\mathrm{B}=10 \mu \mathrm{g} / 1$

\section{Conclusions}

Based on our experience to date, chemical analysis of samples taken for urban and environmental geologic purposes can provide exciting and often new information about the environmental geologic state of the studied areas. The results are valuable on their own as well; however, the analysis of anomalies would require the contribution of local authorities, as well. In our case this contribution was - partially - successful. In our opinion an urban geologic study would make the work of local authorities easier and could complete our view on the subject matter by providing new and valuable information. 


\section{References}

Földváriné Vogl, M. 1975: A területi geokémiai kutatás elméleti és gyakorlati módszerei (Theoretical and practical approaches to regional geochemical research). - MÁFI Alkalmi Kiadvány, Müszaki Könyvkiadó, Budapest, p. 240.

Förstner, U. 1993: Környezetvédelmi technika (Technic of environmental). - Springer Hungarica, Budapest, p. 462.

Guidelines for Drinking-Water Quality - Volume 2: Health Criteria and Other Supporting Information. WHO, Geneva, 1996. Second Edition, p. 973.

KvVM-EüM-FVM regulation 6/2009. (IV. 14.) (Hungary): A földtani közeg és a felszín alatti víz szennyezéssel szembeni védelméhez szükséges határértékekről és a szennyezések méréséről (Legislation in force on the limit values of groundwaters). - http://www.complex.hu/jr/gen/hjegy_doc.cgi? docid $=$ A0900006.KVV

MFGI-MÁFI 2001-2013: Budapest kerületeinek településgeológiai térképsorozata (Urban geological map series of Budapest's districts): III, IV, VIII, XI, XIII, XIV, XV, XVI, XVIII. - MFGI Dep. of Environmental Geology. Manuscript. 